\title{
Can E-Portfolio Improve Students' Readiness to Find an IT Career?
}

\author{
Abdallah Tubaishat \\ Zayed University, Zayed, UAE
}

Abdallah.Tubaishat@zu.ac.ae

\begin{abstract}
An E-Portfolio Assessment Management System (EAMS) can be an innovative tool that provides students with flexible opportunities to demonstrate the acquisition of skills and abilities in an outcome-based institution. The system has been developed and used for the past ten years to create, reflect, revise, and structure students' work. It is a repository management system that facilitates collecting, sharing, and presenting artifacts of student learning outcomes via a digital medium. Therefore, it provides students with flexible opportunities to demonstrate the acquisition of skills and abilities to demonstrate growth of achieving learning outcomes. The rationale of the EAMS is to allow students to demonstrate competences and reflect upon experiences to improve their learning and career readiness; hence, they are accountable for their learning. The system was built around two defined set of learning outcomes: institutionally agreed upon set of learning outcomes, and learning objectives that are related to major requirements.
\end{abstract}

The purpose of this study is to analyze students' perceptions and attitudes when using an eportfolio to support their employment opportunities. The participants were 217 students in the College of Technological Innovation. The students reported that the developing of e-portfolios was extremely helpful. The results showed that students have positive opinions about using eportfolios as a beneficial tool to support their readiness for employment; they believe an eportfolio increases their confidence to find a job in the IT field because it can allow them to showcase artifacts that demonstrate competencies and reflect upon experiences, and they can provide their supervisors during their industrial training with an e-resume that includes views of their actual work of what they have learned and are able to do when they complete their degree. Employers then can review e-portfolios to select prospective employees work readiness skills; hence, graduates are more likely to obtain a job in their workplaces. In conclusion, students do like the idea of e-portfolios when it is presented to them as a career showcase rather than a process for

Material published as part of this publication, either on-line or in print, is copyrighted by the Informing Science Institute. Permission to make digital or paper copy of part or all of these works for personal or classroom use is granted without fee provided that the copies are not made or distributed for profit or commercial advantage AND that copies 1) bear this notice in full and 2) give the full citation on the first page. It is permissible to abstract these works so long as credit is given. To copy in all other cases or to republish or to post on a server or to redistribute to lists requires specific permission and payment of a fee. Contact Publisher@InformingScience.org to request redistribution permission. documenting learning. A career center can use e-portfolios as a tool to help students find a job. Furthermore, our analysis and evaluation uncovered learning issues involved in moving from the traditional approach of learning toward an integrated learning system that can be used after graduation.

Keywords: E-portfolio, IT Career, Learning Curriculum, Student Perspectives, Outcome-Based Higher Education. 


\section{An E-Portfolio as a Career Showcase}

An e-portfolio can be defined as a collection of student work accomplished throughout their time in an academic program (Buzzetto-More, 2006; Lorenzo \& Ittelson, 2014; Love, McKean, \& Gathercoal, 2004; Paulson, Paulson, \& Meyer, 1991; Wheeler, 2014). Hence, an e-portfolio can demonstrate growth of achieving learning outcomes to measure what students have learned and are able to do when they complete their degree. The E-portfolio has been widely used in education for collecting students' artifacts. Buzzetto (2006) indicated that electronic portfolios are a unique way to document student progress, encourage improvement and motivate involvement in learning. Miller and Morgaine (2009) noted that "E-portfolios provide a rich resource for both students and faculty to learn about achievement of important outcomes over time, make connections among disparate parts of the curriculum, gain insights leading to improvement, and develop identities as learners or as facilitators of learning". Chambers and Wickersham (2007) indicated that more and more institutions are moving to use e-portfolio because these "institutions are expected to be more accountable for providing evidence of the process and growth in student learning during their academic progress". Furthermore, "student learning outcomes have become the focus of many universities as a way to measure and document student learning. These outcomes measure how a student's university experience has supported their development as individuals and describes the knowledge, skills, abilities and attitudes students are able to demonstrate upon completion of a program. A learning outcome is not what the instructor does to the student, but rather what the instructor expects the student to do as a result of teaching" (Chambers \& Wickersham, 2007, p. 2). Hence, the process of building e-portfolios in educational institutions encourages the establishment of clear learning goals and expectations. According to Lorenzo and Ittelson (2014) e-portfolios are the biggest innovation in educational technology since the introduction of course management systems such as Blackboard and WebCT. Gulbahar and Tinmaz (2006) indicated that the e-portfolio is one of the newest evaluation techniques for new learning environments in which students show their artifacts, products, and projects as an indication of their functional learning. E-portfolios are being integrated relatively quickly into colleges. The literature illustrates a number of organizational purposes, including meeting requirements from accrediting boards and states' approved technology standards while offering students an alternate form of assessment (Ritzhaupt, Singh, Seyferth, \& Dedrick, 2008). Early pioneers in implementing successful digital portfolios are Alverno College, University of Minnesota, and Indiana University-Purdue University Indianapolis (IUPUI).

In our system, the e-portfolio provides accurate information about the depth and breadth of a student's capabilities in many domains of learning. The system recognizes the following three levels of assessments:

- Student Level: Creating a system of tracking student work over time, in a single course, with students and faculty reflecting on it.

- Course Level: Aggregating many students' work in a particular course to see how the students as a whole are progressing toward learning goals.

- Program level: Assessing many courses in similar ways that are all part of one major and thus, by extension, assessing the entire program of study.

In addition to documenting students' learning, the university view e-portfolio as a tool that helps students in planning for future employment. Furthermore, the e-portfolio assists students in developing resumes and preparing themselves for interviews because it contains a collection of their best academic artifacts. 


\section{Purpose of Study}

Can we help IT students prepare themselves for future employment? To explore that question, we conducted a survey to examine six employment categories to check whether the e-portfolio development process could be used as a beneficial tool to help find relevant jobs. The study is conducted to students majoring in information technology in an outcome-based university.

\section{The Institution under Study}

[It is to be noted that this section is previously published by the author of this paper in the International Journal of Advanced Computer Science and Information Technology (IJACSIT), Vol. 3, Issue 4, 2014, pp. 368-378 (see Tubaishat, 2014).]

The institution under study, Zayed University (ZU), is an academic public institution in the United Arab Emirates (UAE). It offers an academic program that prepares students for success in education, arts, business, media and IT in two campuses: one in Abu Dhabi and one in Dubai. ZU is concerned with "outcome assessments", how learning and growth are measured, evaluated, and demonstrated over years of study. Today, the University is educating more than 9,000 male and female students. The university endeavors to provide students learning opportunities using the American style of education and learning to ensure high quality education. The University is accredited by the Middle States Commission on Higher Education (MSCHE) in 2008. The majority of the faculty members are from North America, Europe, or Australia, or have a terminal degree from universities from developed countries (Zayed University, 2014).

$\mathrm{ZU}$ has an excellent technology infrastructure; its campuses are fully networked and allow students to connect to various university networks and the Internet from anywhere on campus. All the university has wired and wireless connections (classrooms, library, offices, student hubs, cafeteria, etc.). Each student is required to purchase a laptop, and each faculty member receives a laptop with a three-year replacement schedule. Students have easy access to technology in order to facilitate the learning process. Actually, ZU is known as the laptop university in this region. In the College of Technological Innovation (CTI), students have their own laptop loaded with the necessary software for their courses. This helps them complete their work independently without having to be on campus all the time. The CTI College has an independent network infrastructure for teaching and research, in addition to the university's main network. This infrastructure allows students to login remotely into Linux servers to use tools needed for programming languages, databases, and web development courses. Students can also use Linux-based communication tools to collaborate with each other and with instructors. All ZU courses are implemented on Blackboard Learn ${ }^{+}$, a learning management system. ZU students can access Blackboard Learn ${ }^{+}$ from anywhere at any time using a web client.

ZU has adopted an outcome based learning framework to provide a strong focus to the students' learning outcomes and to improve both curriculum and learning practices. The Academic Program Model (APM) was developed by faculty and emphasizes a commitment to a learner-based education and to shift the teaching paradigm to a student learning model. This model focuses on what students can actually do after they graduate. More details about this model can be found in the ZU internal report on "Self-Assessment Based on Accreditation Standards of the Middle States Commission on Higher Education", and the ZU Academic Program Model (Zayed University, 2014). The purpose of the outcome-based model is to provide students with a focused and coherent academic program and to prepare graduates for a rapidly changing and unpredictable future. It is outcome driven and uses the traditional Grade Point Average (GPA) system. The framework that constitutes the academic program model is composed of three components:

- Readiness program to ensure that students are competent in English language 
- General Education

- Degree Major

A major objective of the undergraduate experience at $\mathrm{ZU}$ is the development of the skills necessary for continuous lifelong learning. The APM is designed to help achieve this objective by providing students with a foundation and framework for all university studies. Every ZU course focuses on one or more of the six university-specified learning outcomes. The learning outcomes are incorporated into normal course work and, therefore, are an integral part of disciplinary content and evaluation of the course. Threaded throughout the baccalaureate curriculum, the learning outcomes help students achieve a higher order of intellectual development. ZU has six graduation requirements, called ZU Learning Outcomes (ZULOs), for all students regardless of their major. These requirements are depicted in Table 1 (Zayed University, 2014).

Table 1. Zayed University Learning Outcomes

\begin{tabular}{|l|l|}
\hline Learning Outcome & Description \\
\hline $\begin{array}{l}\text { Information Literacy and } \\
\text { Communication }\end{array}$ & $\begin{array}{l}\text { ZU graduates will be able to recognize information needs, access and evalu- } \\
\text { ate appropriate information to answer those needs, and communicate effec- } \\
\text { tively to a variety of audiences in both English and Arabic. }\end{array}$ \\
\hline Information Technology & $\begin{array}{l}\text { ZU graduates will be critically aware of the implications of information } \\
\text { technology on the individual and on society and be able to use IT to com- } \\
\text { municate and solve problems in an ethical way. }\end{array}$ \\
\hline $\begin{array}{l}\text { Critical Thinking and } \\
\text { Quantitative Reasoning }\end{array}$ & $\begin{array}{l}\text { ZU graduates will be able to use information, reasoning, and creative pro- } \\
\text { cesses to achieve goals and make responsible decisions. }\end{array}$ \\
\hline Global Awareness & $\begin{array}{l}\text { ZU graduates will be able to relate to communities beyond the local, } \\
\text { perceive and react to differences from an informal and reasoned point of } \\
\text { view, and be critically aware of the implications and benefits of cultural in- } \\
\text { teraction. }\end{array}$ \\
\hline Teamwork and leadership & $\begin{array}{l}\text { ZU graduates will be able to work efficiently and effectively in a group. ZU } \\
\text { graduates will be able to assume leadership roles and responsibilities in a } \\
\text { variety of life situations and accept accountability for the results. }\end{array}$ \\
\hline Bilingual & $\begin{array}{l}\text { ZU graduates will be able to communicate effectively (orally and in writing) } \\
\text { in both English and Arabic. }\end{array}$ \\
\hline
\end{tabular}

\section{Outcome-Based Computing Curriculum}

It is to be noted that this section is previously published by the author of this paper in the International Journal of Advance Computer Science and Information Technology (IJACSIT), Vol. 3, Issue 4, 2014, pp. 368-1739, ISSN: 2296-1739, Helvetic Editions, Switzerland (Tubaishat, 2014).

Student learning outcomes have become the focus of many universities as a way to measure and document student learning. Chambers and Wickersham (2007) indicated that "these outcomes measure how a student's university experience has supported their development as individuals and describes the knowledge, skills, abilities and attitudes students are able to demonstrate upon completion of a program". Furthermore, the methods by which these learning outcomes are assessed to determine student success of learning expectations vary and may be dependent upon the course, program, and/or assessment practices and beliefs of the faculty.

The Information Technology program under study strives to meet the demands of government and industry in the UAE technology market. This cooperative process usually includes advisory boards, called National Advisory Council (NAC), where industry leaders communicate the technical needs to faculty and administrators. Currently, the CTI College offers four tracks: Security and Networking, Enterprise Computing, Multimedia Design, and Business Information System. 
All core courses in each sequence include specific university learning outcomes (ZULOs) and specific major learning outcomes (MALOs) that are applicable to the courses contents. The CTI College has established six learning outcomes that complement the learning outcomes of the ZU APM (see Table 2). These major learning outcomes form the basis for analysis and assessment that play an essential role in the continuous process of improvement.

Table 2 Major Learning Outcomes for CTI College

\begin{tabular}{|l|l|}
\hline Learning Outcome & Description \\
\hline $\begin{array}{l}\text { Critical Thinking and Quan- } \\
\text { titative Reasoning in IT }\end{array}$ & $\begin{array}{l}\text { CTI College graduates will be able to use critical thinking and } \\
\text { quantitative processes to identify, analyze and solve problems, } \\
\text { and evaluate solutions in an IT context. }\end{array}$ \\
\hline $\begin{array}{l}\text { Information Technology } \\
\text { Application }\end{array}$ & $\begin{array}{l}\text { CTI College graduates will be able to select existing and cutting- } \\
\text { edge IT tools and procedures to develop modules and systems. }\end{array}$ \\
\hline $\begin{array}{l}\text { Information Technology } \\
\text { Management }\end{array}$ & $\begin{array}{l}\text { CTI College graduates will be able to assess and determine infor- } \\
\text { mation resource requirements to develop solutions suitable for IT } \\
\text { and business managers operating in a multi-national and multi- } \\
\text { cultural environment. }\end{array}$ \\
\hline $\begin{array}{l}\text { Information Technology } \\
\text { Professional Practice }\end{array}$ & $\begin{array}{l}\text { CTI College graduates will be able to work effectively in individ- } \\
\text { ual and group situations, understand how groups interact, be able } \\
\text { to assume a leadership role when required, and understand the } \\
\text { fundamentals of professional and ethical conduct. }\end{array}$ \\
\hline $\begin{array}{l}\text { Information Technology } \\
\text { Systems Theory and Practice }\end{array}$ & $\begin{array}{l}\text { CTI College graduates will be able to understand and communi- } \\
\text { cate the fundamentals of systems theory in the development of } \\
\text { appropriate systems that function in a global environment. }\end{array}$ \\
\hline $\begin{array}{l}\text { Technical Communication } \\
\text { (Bilingual) }\end{array}$ & $\begin{array}{l}\text { CTI College graduates will be able to express themselves effec- } \\
\text { tively and efficiently in both English and Arabic while using the } \\
\text { correct IT terms for each language. }\end{array}$ \\
\hline
\end{tabular}

\section{E-Portfolio: How It Works?}

It is to be noted that this section is previously published by the author of this paper in the International Journal of Advance Computer Science and Information Technology (IJACSIT), Vol. 3, Issue 4, 2014, pp. 368-1739, ISSN: 2296-1739, Helvetic Editions, Switzerland (Tubaishat, 2014).

The EAMS is an important resource used in the colleges for various assessment activities. The system is a searchable, electronic storage tool into which specific examples of student work are uploaded from various courses across the curriculum. Students regardless of their major start using EAMS in semester three of their degree programs and therefore, they begin the development of a working e-portfolio by archiving assignments, instructors' feedback and reflections during early courses.

In each course in the Information Technology concentrations, faculty members are required to assign assignments designed to assess at most two of the six MALOs presented in Table 2. Because the e-portfolio assignments are the key to the success of the outcome assessment process, faculty members are encouraged to design assignments that provide students with an opportunity to demonstrate their most distinguished performance and scholarly accomplishments. Examples of appropriate e-portfolio assignments include a term paper, a project work, a programming assignment, or a network design. Faculty members are required to provide a criteria sheet for each portfolio assignment that explains the purposes and the learning objectives assessed. After reviewing student work, the faculty comments on the student's work and posts their feedback in a designated area of the EAMS. Moreover, the faculty evaluates both the assignment's general ef- 
fectiveness and its level of accomplishment with respect to the desired outcome(s). Students are able to access the faculty comments from the EAMS, as well as any other work posted on the system. This process enables students to update their work and reflect on their learning. The EAMS was designed to function as an archive for research on the effectiveness of various courses in achieving learning outcomes. Because all major student work is uploaded to the system, research into student achievement of learning outcomes in courses or sequences of courses can be easily carried out. Furthermore, student work can be sorted and studied either by course or by outcome. Figure 1 shows the EAMS interface. The interface shows for a particular faculty member the courses being taught as well as the assessment criteria posted by the instructor. It allows him/her to select term code and the courses in that semester through accessing e-portfolio systems via the Intranet or extranet.

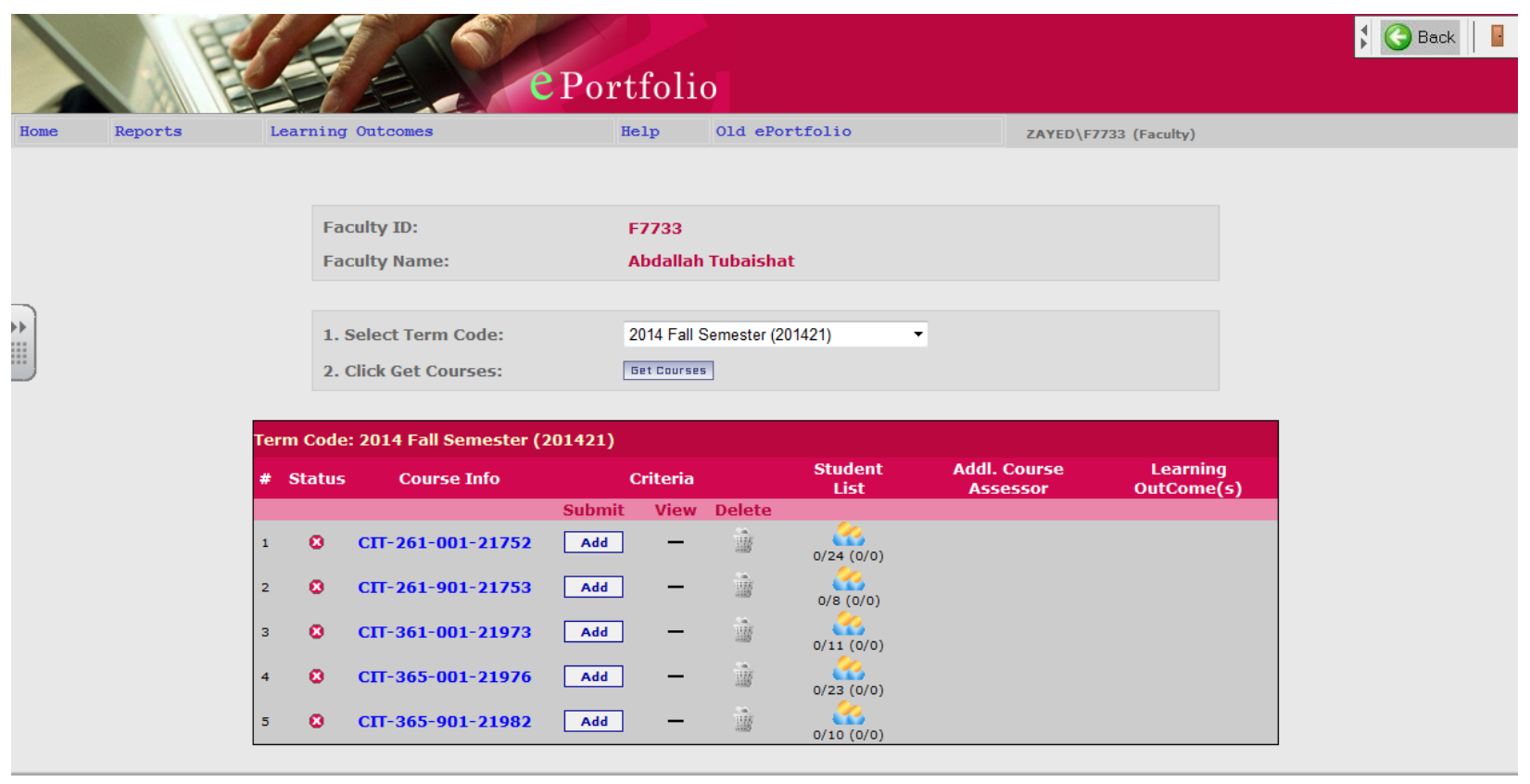

Figure 1: E-Portfolio Assessment Management System Interface

After matching courses with learning outcomes, faculty members develop key assignments for the courses to optimize targeted learning. The assignments include a term paper, a lab exercise, a design for building a network, or a case study. After grading the piece of evidence, the instructor posts the assessment feedback. The students can then access the instructor's assessment/feedback and modify their work. Finally, the students have the option to include that piece of evidence as an artifact in their e-portfolio.

It is to be noted that the CTI College has accumulated a significant amount of data from the EAMS to evaluate students' achievements. Figure 2 shows another snapshot of the EAMS for a Course Review Report. In this view, we can generate specific reports about semester, course(s), and type of assignments (e.g., Project, Term Paper, presentation, etc.). 


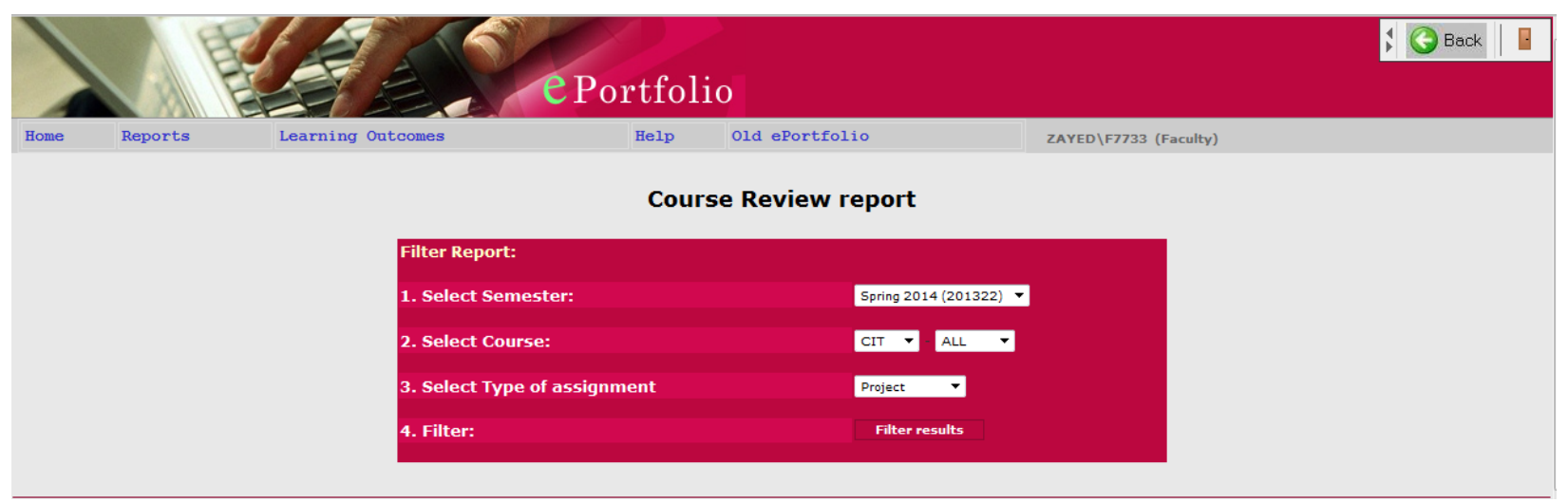

Figure: 2 e-portfolio Course Review Report

\section{Case Study}

The purpose of the study was to analyze students' perceptions of using an EAMS to support their readiness for employment and to check whether the e-portfolio development process can be used as a beneficial tool to help students find relevant jobs. The specific research questions that guided the study are shown in Table 3.

Table 3 Research Questions

\begin{tabular}{l} 
Can e-portfolio help students showcase their academic experiences for potential employ- \\
ers? \\
Can e-portfolio be used as a beneficial tool to get a job in the IT field? \\
Can e-portfolio be used as a component of students resume to apply for jobs? \\
Can e-portfolio help students find a good job? \\
\hline Can e-portfolio improve students' confidence to find a good job? \\
Can e-portfolio help employers get a better understanding of students' skills and abili- \\
ties?
\end{tabular}

\section{Participants}

The participants of the study were volunteered randomly from the baccalaureate program majoring in Information Technology from all levels. The institution is a public outcome-based university located in the Gulf region. Data was distributed to 268 students and collected from 217 students with response rate 81\%, 145 female, and 72 male. Data was collected in Spring 2014 through an online questionnaire. The survey was distributed online. The questionnaire was made up of six closed-ended questions with five multiple choice questions (Strongly Disagree, Disagree, Undecided, Agree, Strongly Agree).

\section{Survey Analysis}

A survey questionnaire was developed to gather data to try to find an answer to the above questions and learn about the student's attitudes and opinions about e-portfolio as a tool to support their readiness for employment. Six questions were developed to gather the data needed to answer the research questions. Table 4 shows all the questions with the respective students' responses and analysis. 
Table 4 Questionnaire Response Analysis

I will use my e-portfolio to showcase my academic experiences for potential employers: The first question was designed to learn about the student's opinion on whether they will use e-portfolio to showcase their academic experiences for potential employers. Around 66 percent responded with agreement (or strongly agreed) to a question regarding showcasing their academic experiences for potential employers. Around 24 percent of the students were undecided about that perception and only 10 percent disagreed or strongly disagreed about their intent of using e-portfolio to showcase their academic experiences for potential employers.

I consider my e-portfolio as a beneficial tool to get a job in the IT field: The second question was designed to learn about the possibility that e-portfolio tool can help students get a better job in the IT field. The statistics were very close to the responses to the first question where around 63 percent of the students responded by either agreed or strongly agreed to the fact that e-portfolio can be used as a beneficial tool to get a job in the IT field. About 24 percent were undecided, and 13 percent either disagreed or strongly disagreed that using eportfolio can be used as a beneficial tool to get a job in the IT field.

I will use my e-portfolio as a component of my resume to apply for jobs: This question was designed to learn about if students will use e-portfolio as a component of their resume when applying for a job. More than two third ( 75 percent) of the students indicated that they will use their portfolio when applying for a job. About 12 percent were undecided, and 13 percent either disagreed or strongly disagreed with that statement.

I believe my e-portfolio will help me find a good job: This question was designed to learn about if students believe that e-portfolio will help them find a good job. Around 61 percent responded with agreement (or strongly agreed) to a question regarding the student's opinion that e-portfolio will help them find a good job. Around 22 percent of the students were undecided about that perception, and 17 percent disagreed or strongly disagreed about the statement, e-portfolio will help me find a good job.

My e-portfolio has increased my confidence to find a good job: This question was designed to learn about the possibility that the e-portfolio tool helped students increase their confidence to find a good job. Around two third (72 percent) of the students indicated that eportfolio has increased their confidence to find a good job. The rest of the students' responses were divided between undecided and disagreement (about 14 percent were undecided, and 14 percent either disagreed or strongly disagreed with that statement).

I believe potential employers will like the content of my e-portfolio: The last question was designed to learn about the student's opinion on whether potential employers will like the content of their e-portfolio. Sixty percent of the students responded in agreement to a question regarding potential employers will like the content of their e-portfolio. Around 28 percent of the students were undecided about that perception, and only 12 percent disagreed or strongly disagreed about potential employers will like the content of their e-portfolio.

\section{Future Enhancements}

Over ten years, our institution has identified, researched, and developed an e-portfolio tool that meets the needs of students, faculty, and administrators. The tool is easy to use. Regarding our research questions and statistics for the student's view of using e-portfolios, we can confirm that students studying in the College of Technological Innovation have positive attitudes towards using the e-portfolio to support their employment opportunities. Currently, e-portfolios can only be used by current students. A future goal is to allow students to keep their e-portfolio after graduation. Furthermore, more cases covering courses, digital divide, geographical constraints, various institutions in different categories can be carried out in the future. 


\section{Conclusions}

An E-Portfolio Assessment Management System (EAMS) has been developed and used in an outcome-based university to create, reflect, revise, and structure students' work via digital medium. A survey was conducted to learn about student's opinion and attitude toward using eportfolios as a beneficial tool to support their readiness for employment. The students reported that the developing of e-portfolios was extremely helpful. The results showed that students believe e-portfolios increased their confidence to find a job in the IT field because they can allow them to showcase artifacts that demonstrate competencies and reflect upon experiences. Career center may view e-portfolios as a tool to help students find a job. In providing a link to an eportfolio in students' resumes, graduates can lead potential employers directly to their best work. Hence, they can have a more meaningful discussion during the interview process. When graduates are short listed and asked to conduct a face-to-face interview with potential employer, their eportfolio can be used as a strong support in their presentation.

\section{References}

Buzzetto-More, N. (2006). The e-Learning and business education paradigm: Enhancing education, assessment, and accountability. Proceedings of the Maryland Business Education Association Conference. Ocean City, MD.

Chambers, S., \& Wickersham, L. (2007). The electronic portfolio journey: A year later. Education Journal, 127(3), 351-360.

Gulbahar, Y., \& Tinmaz, H. (2006). Implementing project-based learning and e-portfolio assessment in an undergraduate course. Journal of Research on Technology in Education, 38(3), 309-327. Retrieved from http://www.tandfonline.com/toc/ujrt20/38/3

Lorenzo, G., \& Ittelson, J. (2014). An overview of e-portfolios. Retrieved 8 October, 2014 from http://www.case.edu/artsci/cosi/cspl/documents/eportfolio-Educausedocument.pdf

Love, D., McKean, G., \& Gathercoal, P. (2004). Portfolios to webfolios and beyond: Levels of maturation. EDUCAUSE Quarterly, 27(2), 24-37.

Millar, R., \& Morgane, W. (2009). The benefits of e-portfolios for students and faculty in their own words. AAC\&U, pp. 8-12, Winter.

Paulson, F. L., Paulson, P. R., \& Meyer, C. (1991).What makes a portfolio a portfolio? Educational Leadership, 48(5), 60-63.

Ritzhaupt, A., Singh, O., Seyferth, M., \& Dedrick, T. (2008). Development of the electronic portfolio student perspective instrument: An ePortfolio integration initiative. Journal of Computing in Higher Education, 19(2), 47-71. Retrieved from http://link.springer.com/article/10.1007/BF03033426

Tubaishat, A. (2014). E-portfolio assessment for learning: Ten years later - An experience from an outcome-based university. International Journal of Advanced Computer Science and Information Technology (IJACSIT), 3(4), 368-378. Retrieved from http://elvedit.com/journals/IJACSIT/wpcontent/uploads/2015/01/E-Portfolio-Assessment-for-Learning.pdf

Wheeler, B. C. (2014). E-Portfolio Project, Open Source e-Portfolio Release. Andrew W. Mellon Foundation, Version 2.0, Retrieved September 11, 2014 from: http://juicy.mellon.org/RIT/MellonOSProjects/\%20e-Portfolio/Portfolio_Proposal_Public.doc

Zayed University. (2014). Internal report on self-assessment of Zayed University based on accreditation standards of the middle states commission on higher education. Available at http://www.ZU.ac.ae 


\section{Biography}

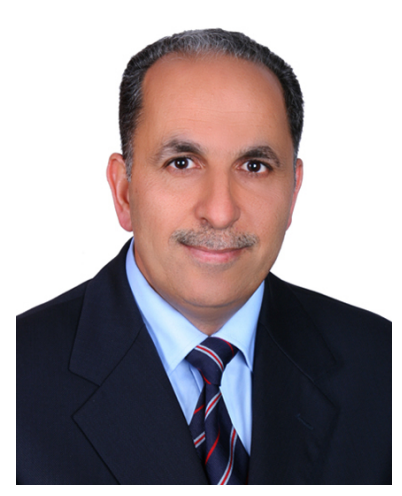

Abdallah Tubaishat is an Associate Professor in the College of Technological Innovation at Zayed University, United Arab Emirates. He received his $\mathrm{PhD}$ in Software Engineering from Illinois Institute of Technology, IL, USA in 1994. Dr. Tubaishat has twenty years of experience in teaching and research. His teaching experience include: Software Engineering, Database and Programming, His research spans two main areas, one is technical: software engineering, and the other is non-technical: e-learning, and educational technology. He has published a book with others entitled "Computer Skills", and has around twenty three Journal and conference publications. Dr. Tubaishat served on the program and organizing committees of several international conferences and workshops. 